\title{
Vocabulary Development in Science: Studying a Middle School Sheltered Classroom
}

\author{
Ying Zhang \\ Dept. of Education, Robert Morris University \\ 6001 University Blvd, Moon Township, PA, 15108, U.S. A. \\ Tel: 1-412-397-5918Ｅ-mail: zhang@ @rmu.edu
}

Received: September 8, 2017 Accepted: October 14, 2017 Published: October 20, 2017

doi:10.5296/gjes.v3i2.11825 URL: https://doi.org/10.5296/gjes.v3i2.11825

\begin{abstract}
This article reports how science literacy development, particularly vocabulary development occurred in a sixth-grade sheltered science classroom as a part of an eight-month ethnographic study. Specifically, the research asks how language development occurs in the science classroom from the perspective of social semiotics. The study takes a multimodal social semiotic perspective to examine how English Learners (ELs) make meaning of science vocabulary. Qualitative methods are used and the data include video and audio recordings of science lessons, field notes, formal and informal interviews with teacher and students, and classroom artifacts. Findings demonstrate that although science vocabulary was embedded in the multimodal science curriculum, actual language development was limited. The study expands the current knowledge base for developing literacy skills in science and challenges researchers and educators to reexamine the current practice on how to incorporate effective literacy education in the content area of science.
\end{abstract}

Keywords: English learners, Science, Vocabulary, Literacy, Sheltered classroom 


\section{Introduction}

Recent research about science education and English Learners (ELs) addresses the dual focus on the content mastery and language development in classroom instruction (Quinn, Lee, \& Valdés, 2012; Rosebery \& Warren, 2008). Due to the fact that many science teachers are not traditionally trained to address ELs' needs by focusing on the language, many studies explore the effective of professional development for in-service mainstream/sheltered classroom teachers (Amaral, Garrison, \& Klentschy, 2002; Lara-Alecio et al., 2012; Lee, Penfield, \& Buxton, 2011; Santau, Maerten-Rivera, \& Huggins, 2011; Santau, Secada, Maerten-Rivera, Cone, \& Lee, 2010; Shanahan \& Shea, 2012; Weinburgh, Silva, Smith, Groulx, \& Nettles, 2014; Zwiep, Straits, Stone, Beltran, \& Furtado, 2011). Some also advocate for language training for preservice teachers (Stoddart, Bravo, Solis, Mosqueda, \& Rodriguez, 2011). These studies demonstrate that in order for ELs to improve their academic performance in science, the literacy components must be addressed specifically. However, although these studies often take the quantitative or mixed-methods approach to focus on the students' achievement gain, they may lack detailed descriptions about the day-to-day classroom instruction in which the content learning and language development occur. This article reports the vocabulary development portion of a qualitative ethnographic study of science learning in a sixth-grade sheltered classroom (see Zhang, 2016). Examining the classroom teaching and learning from the perspective of social semiotics, the study shows that although science vocabulary was deliberately addressed and emphasized by the science teacher, the vocabulary was taught in a separate manner from the science content. This leads to a semiotic discrepancy between the science content and science language. This article further addresses implications for teaching practices and future research.

\section{Theoretical Framework and Literature Review}

This study examines the science vocabulary development through the lens of social semiotics. Social semiotics concerns about signs and meanings (Hodge \& Kress, 1988). Language, although is probably the most-studied sign system (Halliday, 1978), is indeed embedded and is interacting with other sign systems, as Palmer (1996) has pointed out, "language is the play of verbal symbols that are based on imagery. Our imaginations dwell on experiences obtained through all the sensory modes, and then we talk." (p. 3) From the social semiotic perspective, language is thus one of the symbols that interacts with other "semiotic resources" (Van Leeuwen, 2005, p. 3) to make meanings of the world. In the "meaning-making system" (Kress, Jewitt, Ogborn, \& Tsatsarelis, 2001, p. 15), language, as one communicative mode, relies on and interact with other modes to co-present a meaning. When making sense of science words, for example, it is interesting to see how the learning happens when multiple modes, such as the physical modeling, gestures and visual images co-mediate the process.

In the field of EL science education, researchers realize the importance of literacy development to foster science understanding (Amaral et al., 2002; Buxton, Lee, \& Santau, 2008; Lara-Alecio et al., 2012; Santau et al., 2011; Santau et al., 2010; Shanahan \& Shea, 2012). Lemke (1990) proposed that students need to "speak at greater length (in monologue and dialogue)" (p. 168), because talking science not only helps the students to polish their scientific 
understanding but also aids their language acquisition. More recently, there has been a discussion about creating opportunities for ELs to use academic language to construct their learning in schools (Quinn et al., 2012; Valdés, Kibler, \& Walqui, 2014; Van Lier \& Walqui, 2012). Researchers agree that students need to be actively engaged in using language in "deliberate, well-constructed" (Walqui, 2011, p. 163) instruction.

Many studies focus on the students' science achievement (and sometimes, language development) resulted from teacher professional development that focuses both on science content and language learning (Lara-Alecio et al., 2012; Lee et al., 2011; Santau et al., 2011; Santau et al., 2010; Shanahan \& Shea, 2012; Zwiep et al., 2011). For example, Santau and colleagues (2011) studied fourth-grade ELs' science achievement resulting from a three-year professional intervention that targeted both on science and literacy. Positive results indicated the intervention was successful. Shanahan and Shea's (2012) study about the professional development of English and science teachers also demonstrated a significant increase in students' science talk, teacher learning, and teacher efficacy. Although research agrees that literacy components must be embedded in the science curriculum, few studies have documented how language studies are conducted in science classrooms. In this sense, this research, by closely describing what happens in learning the science vocabulary, may contribute to the overall understanding of ELs' content learning by providing a detailed picture of the relationship between language and content.

\section{Methods}

\subsection{Research Question}

The study examines ELs' science learning and language learning experiences in a sixth- grade sheltered classroom. A sheltered classroom contains ELs only. The research question asks how language development occurs in the science classroom from the perspective of social semiotics.

\subsection{Participants and Setting}

The research site is located in a middle school near a university town in the Midwestern region of the United States. Fourteen percent of the students were identified as ELs in the year when data collection occurred. The school offered ESL classes and sheltered instruction using the Sheltered Instruction Observation Protocol (Echevarria, Vogt, \& Short, 2012), also called the SIOP model. Four teachers (English language arts, social studies, science, and math) were selected to teach in the sheltered classroom based on their willingness and personal experience. None of these four teachers held a credential in English as a Second Language (ESL), but all of them attended multiple SIOP training sessions.

The focal classroom contained 18 ELs who had an average English Language Proficiency Level of Level 3, as identified by the LAS Links test required by the State Department of Education. (See Appendix 1 for detailed information about the English Language Proficiency Levels.) Although all students were given the assent and consent forms prior to the study, four students, including two males and two females were selected to represent a wide range of students. More specifically, the decision was based on 1). the students' willingness to 
participate in the study identified by the signed assent and consent forms; 2) the students' interest levels in science indicated by the teacher's classroom survey; and 3) the students' Language Proficiency Levels shown by the LAS Links test results. The four focal students showed different Language Proficiency Levels in reading, ranging from Level 2 to Level 5. Nonetheless, they demonstrated the same overall Language Proficiency Levels across the four domains (listening, speaking, reading and writing).

All focal students spoke Spanish as their first language. The two male focal students, Eloy (pseudonym) and Santos (pseudonym), were both 12 years old. Eloy spoke fluent English but had difficulties in writing. He was attentive in the classroom and enjoyed science and math. Santos enjoyed using conversational English to communicate with others. He was described as a "smart" student but only engaged the learning when he was interested. The two female students, Marta (pseudonym) and Ysabel (pseudonym) were good friends. Ysabel had the highest LAS Links test score in the class and showed strong linguistic competence in reading and writing. Marta, on the other hand, had the lowest reading score among the four focal students and thus relied heavily on Ysabel for classroom activities. Marta was also shy, not willing to raise hands for questions or help.

The science teacher, Mrs. Harry (pseudonym), had 35 years of teaching experience. She had a license at the elementary level (K-6) but was not certified in either ESL or science. Mrs. Harry's background included working with "disadvantaged children," whom she believed shared many similarities with ELs.

\subsection{Data Collection}

In total, 39 class sessions were observed and videotaped, which covered a range of science topics, including physical science, life science, and earth science. The 39 class sessions were divided into 4 types: A. the vocabulary learning sessions, where the majority of time is given to vocabulary learning activities; B. the lecture sessions, where the majority of time is given to the lecture about a specific science topic, such as living things and non-living things; C. the lab sessions, where the majority of time is given to the science investigations; and $\mathrm{D}$. the language experience sessions, where the majority of time is given to address literacy development but not the science content.

Different types of data were collected, including:

1) Video recordings of the classroom instruction: Two video cameras were used with one facing the teacher at the back of the classroom and another one facing the four focal students who were grouped and placed on one side of the classroom. Each video lasted for 45 minutes.

2) Audio recordings of the student participants' speech: Each focal student's speech was captured by a microphone pinned to their collar. The microphones were then connected to a separate audio recording device placed on the ground. Because the male students naturally spoke in a louder volume, their speech was more audible. The audio recordings were transcribed individually and then combined with the video data to closely capture the classroom scenes. 


\section{$\Lambda$ Macrothink}

Global Journal of Educational Studies

ISSN 2377-3936

2017, Vol. 3, No. 2

3) Field notes: Field notes included descriptive notes and reflective notes (Bogdan \& Biklen, 2006).

4) Formal and informal interviews with the participants: All formal interviews followed the pre-designed interview protocol (see Appendix 2). Informal interviews were held during the class breaks and were recorded in the margins of the field notes.

5) Classroom artifacts: Classroom artifacts included all the textbook pages that were read or discussed, student products and teacher products, classroom worksheets, lab sheets, journal entries, science projects, vocabulary cards, visual displays, computer files, and the teacher's writing/drawing on the board.

\subsection{Data Analysis}

Data analysis involved four steps: sampling video data, transcribing and representing data, designing the units of analysis, and looking for patterns and themes.

\subsubsection{Sampling Video Data}

Because the video data naturally involve linguistic and non-linguistic aspects of communication, how to transcribe the rich data becomes an issue. For this study, 770 minutes out of 1755 minutes of video data were selected for analysis, because it was not feasible to transcribe and analyze every single second of the data (Jewitt, 2006). Data were selected to reflect moments when 1. learning appeared to occur in the classroom; and 2. transduction across modes — "transitions from one mode of representation to another" (Kress, 1997, p. 29) occurred.

\subsubsection{Transcribing and Representing Data}

Up until now, there has not been a satisfactory method to transcribe and represent multimodal data (Flewitt, Hampel, Hauck, \& Lancaster, 2009). One of the popular methods is to use a multimodal matrix to simultaneously include the participants' speech, gestures, visual displays, and other communicative modes involved. For this study, a two-column multimodal matrix was designed. The first column was for speech as it was the primary communicative tool for classroom instruction. The second column was for nonverbal behavior, which included gaze, gesture, and action. This decision was made to address the linguistic and non-linguistic aspects of the classroom communication.

\subsubsection{Designing Units of Analysis}

Layered units of analysis (see Figure 1) were designed to closely examine the classroom interaction across participants and modes. 


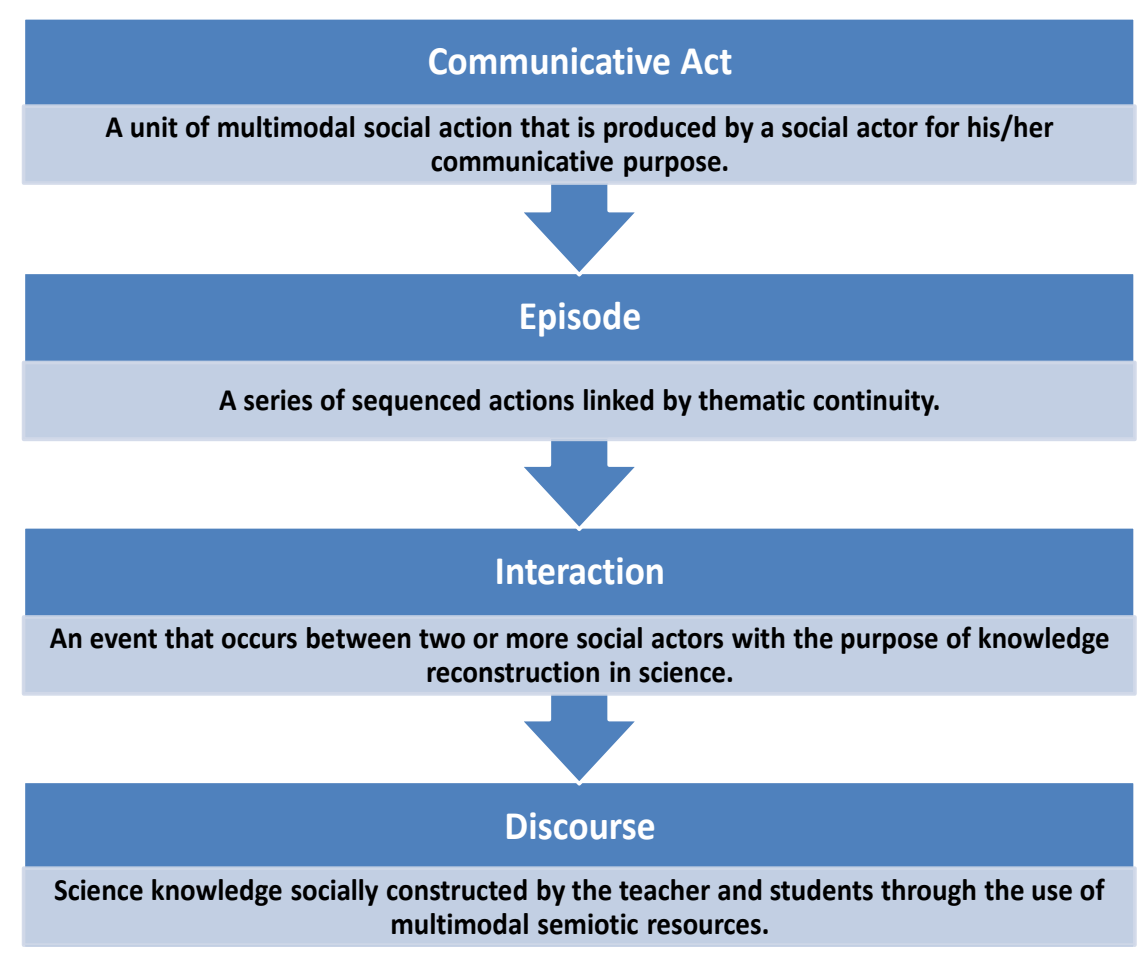

Figure 1. Units of analysis

The broadest and most comprehensive unit of analysis is the discourse. Science classroom discourse in this study refers to science learning socially constructed by the teacher and students through the use of multimodal semiotic resources. This echoes what Gee (1999) has proposed-discourse with the big " $D$ ". Discourse is realized through interactions (Britsch, 2005; 2009). An interaction is an event that involves two or more actors who shape and reshape each actor's teaching and learning of the science content. An interaction implies a thematic unity, for example, a teacher presentation on one science topic is considered as an interaction. In this study, among the 39 class sessions observed, 46 interactions were identified, including 21 teacher presentation interactions, 9 peer work interactions, and 16 individual work interactions. An interaction can be further broken down into multiple "episodes," (Garvey, 1984, p. 79) defined as a series of sequenced actions linked by thematic continuity. For example, a teacher presentation includes three episodes: initiation, elaboration, and transition or end. Within an "episode," (Garvey, 1984, p. 79) multiple "communicative acts" (Van Leeuwen, 2004, p. 8) may occur. A "communicative act" refers to what the social actor is doing, and thus is multimodal. A communicative act can be a speech utterance, an action, a gesture, or a combined unit of multiple modes, such as a speech utterance and a "speech-related gesture" (Knapp \& Hall, 1997, p. 263).

\subsubsection{Looking for Patterns and Themes}

After designing the units of analysis, all data transcripts were then coded. The coding process started with one episode within one interaction type (e.g., action episode within a peer work, 
Feb. 22), then the researcher coded another parallel episode either from the same interaction type (e.g., action episode within a peer work, May. 6) or from another interaction type (e.g., action episode within an individual work, May 8). Then the researcher compared codes across episodes and interactions to seek emerging patterns. As linguistic and non-linguistic data were collected, codes were also organized into different categories, such as the semiotic functions and pragmatic functions (see Appendix 3). To ensure credibility, both the author and two faculty members from the author's previous institution examined the coding categories and their relation to the research question. Following the inductive method (Bogdan \& Biklen, 2006), themes were then identified.

\section{Results}

One of the major findings of the study was that although vocabulary learning was incorporated into the multimodal science discourse, little language development occurred in the classroom. Since the vocabulary learning was predominantly addressed in the vocabulary learning sessions, this article will focus on this session type only.

In the vocabulary learning sessions, students spent most of the time learning new vocabulary. Vocabulary learning sessions always occurred at the beginning of a science unit, when the teacher viewed the vocabulary as a "prerequisite for content learning." In her view, "Kids can learn better if they have the language background."

A typical vocabulary session began with a teacher presentation where the teacher introduced the science vocabulary to the students and assigned tasks for the subsequent individual work. The individual work involved having students (a) copy the words and their definitions on a vocabulary worksheet, (b) cut the worksheet to make individual vocabulary cards, and (c) match definitions with words. During the process, students engaged with non-academic semiotic functions such as procedural and social functions.

Teacher presentation. In a teacher presentation, the teacher introduced the pre-selected vocabulary for her ELs. The selection was based on the curriculum and on the teacher's understanding of her students. In her words, "These ELs are not like regular smart children who can grasp the concept by having a teacher just running through the content. They have to have the vocabulary first." A typical vocabulary list contained fewer than ten words with the majority as science nouns.

The teacher introduced the vocabulary either by having students mark the key words in their textbooks or by providing a ready-made vocabulary list. When doing so, the teacher usually asked individuals or the whole class to read the vocabulary aloud, or she read the words herself. The teacher paid specific attention to pronunciation; as she stated in her interview, "Pronouncing the words correctly is important." Sometimes, the introduction was done multimodally, with visual aids, such as the textbook illustrations or self-created images. However, these visual modes did not provide enough contextual support for students to gain a deeper understanding of the vocabulary.

The following data excerpt (See Table 1) shows how the teacher introduced the vocabulary with a visual diagram of the microscope. 


\section{Al Macrothink}

Global Journal of Educational Studies

ISSN 2377-3936

2017, Vol. 3, No. 2

Table 1. Data transcript excerpt 1

\begin{tabular}{|c|c|c|c|}
\hline Line & $\begin{array}{l}\text { Coding } \\
\text { Categories }\end{array}$ & Speech & Nonverbal Behaviors (actions/gaze) \\
\hline $\begin{array}{l}1 \\
2 \\
3 \\
4 \\
5 \\
6\end{array}$ & $\begin{array}{l}\text { Introducing } \\
\text { the } \\
\text { vocabulary } \\
\text { Asking for } \\
\text { read-aloud }\end{array}$ & $\begin{array}{l}\text { T: Let's take a look at this together for a } \\
\text { minute. Eyepiece, body tube..... How } \\
\text { about this one? }\end{array}$ & $\begin{array}{l}\text { T pulled out a microscope diagram and } \\
\text { showed it on the whiteboard. T pointed } \\
\text { to different parts and read the names } \\
\text { printed on the diagram. E looked at the } \\
\text { T. S held the scissors up and cut in the } \\
\text { air. He sometimes looked at the window. }\end{array}$ \\
\hline 7 & Read-aloud & Ss: Nosepiece. & T pointed to "nosepiece." \\
\hline 8 & & T: OK, nosepiece. & \\
\hline 9 & Read-aloud & E: Revolving. & \\
\hline $\begin{array}{l}10 \\
11\end{array}$ & & $\begin{array}{l}\text { T: Revolving, great! Revolving } \\
\text { nosepiece. Lots of time I will call it the } \\
\text { nosepiece. }\end{array}$ & S looked at E. \\
\hline 12 & Read-aloud & Ss: Objective lens. & \\
\hline $\begin{array}{l}13 \\
14 \\
15 \\
16 \\
17 \\
18 \\
19 \\
20 \\
21 \\
22 \\
23 \\
24 \\
25 \\
26 \\
27\end{array}$ & $\begin{array}{l}\text { Describing } \\
\text { (the } \\
\text { vocabulary) }\end{array}$ & $\begin{array}{l}\text { T: Yes. That's the one some kids have. } \\
\text { They know their lenses. They get that } \\
\text { part, but you have to refer to them as the } \\
\text { objective lens, and notice there are three, } \\
\text { different ones? The nosepiece allows } \\
\text { you to turn it so that you can use the } \\
\text { objective lens you want. Makes a } \\
\text { difference. The little one shows you } 40 \\
\text { times big like if you are using it to look } \\
\text { at an insect eye, that insect eye will be } \\
40 \text { times bigger than it really is. If you } \\
\text { turn to the one in the middle, you will } \\
\text { look at the insect eye } 400 \text { times bigger. } \\
\text { To get this, to get what you want, you } \\
\text { use the nosepiece and rotate. OK, let's } \\
\text { look at another part quickly. }\end{array}$ & $\begin{array}{l}\text { E and S looked down. } \mathrm{M} \text { and } \mathrm{Y} \text { looked } \\
\text { straight at the board. E held the scissors } \\
\text { as well. } \\
\text { T pointed to the diagram. } \\
\text { S continued manipulating his scissors } \\
\text { and began to cut the hair on his arm, and } \\
\text { then he used another hand to clean the } \\
\text { rest of the hair left on the arm. M } \\
\text { watched S. S then accidentally cut his } \\
\text { finger and made a loud sound. E looked } \\
\text { at him, wondering what happened. S } \\
\text { ensured E he was ok and put his finger } \\
\text { into his mouth to suck on it. }\end{array}$ \\
\hline 28 & Read-aloud & Ss (including E): Arm & $\mathrm{M}$ and $\mathrm{Y}$ sat on their seats and did not \\
\hline 29 & & T: Arm & read the words on the board. \\
\hline 30 & Read-aloud & Ss (including E): stage & \\
\hline 31 & & T: Stage & \\
\hline
\end{tabular}

In this vocabulary learning session, the teacher introduced the vocabulary with a teacher-created visual diagram of the microscope (see Figure 2). 


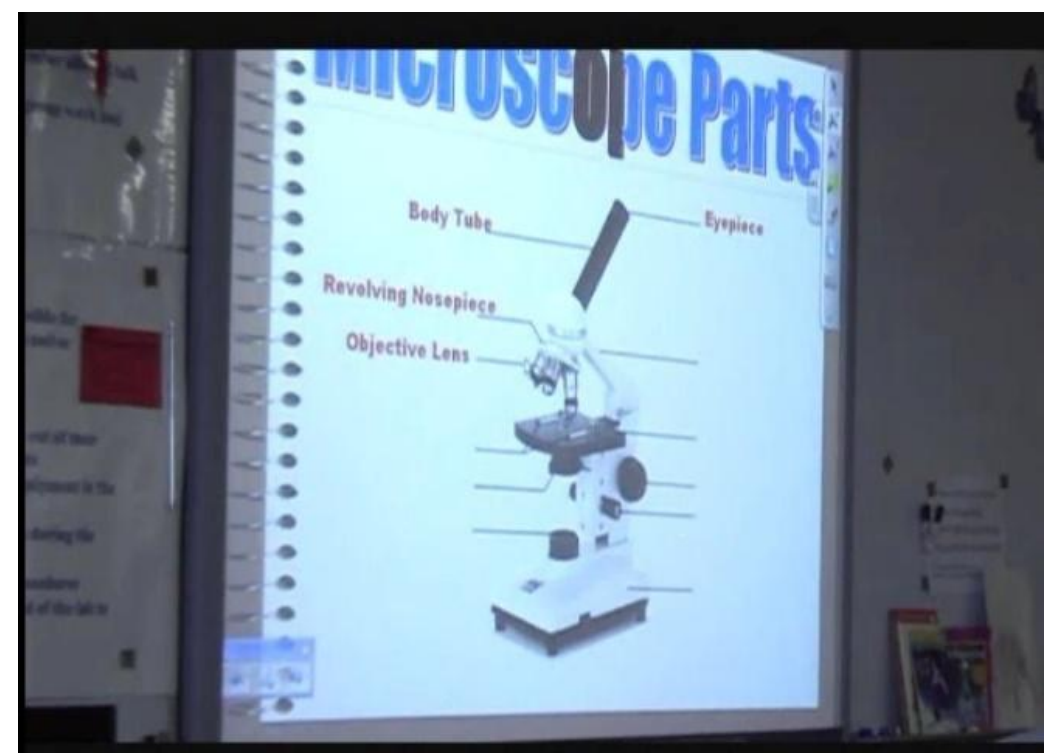

Figure 2. Teacher-created visual diagram of the microscope

The diagram contained a microscope with its parts identified by science nouns. The teacher introduced the vocabulary by clicking the computer first, so a word appeared on the screen. She then had all the students read aloud single words; for example, when the teacher pointed to the word "nosepiece," the students read "nosepiece," and the teacher repeated, "OK, nosepiece" (Line 8). She followed this pattern until she finished all the words.

As shown in lines 17-28 from Table 1, the teacher described the noun phrase "objective lens" by pointing to the diagram and describing the function of each objective lens; however, during this explanation three focal students, Santos, Eloy, and Marta, were attending to their own business and did not pay attention to the teacher (Lines 21-27). It's also worth pointing out that the teacher's introduction of the terms "objective lens" and "rotate the objective lens" were not linked to an experiential context. As a result, the students' engagement with the vocabulary was restricted to merely pronouncing the words. Among the four focal students, only Eloy followed the teacher by reading the words aloud (Lines 9, 30, and 32). The other three focal students were either engaged in off-task behavior (i.e., Santos) or were just looking at the diagram without reading (i.e., Ysabel and Marta, Lines 30-31).

Thus, although multimodal teaching was involved, the vocabulary introduction was consistently distinct from the students' experiential or conceptual background. In another word, the introduction remained at an abstract level of citing definitions with little contextual support, which was usually restricted to one textbook page or a visual diagram. During this process, the students' engagement with the vocabulary was through pronouncing the words, hearing the words, and looking at the words and their definitions in the textbook.

Individual work. The teacher presentation in a vocabulary learning activity session generally lasted for 10-15 minutes, after which the class moved to individual work. In individual work, the students copied the words and their definitions on a vocabulary worksheet, cut the worksheet to make individual vocabulary cards, and matched the definitions with the words. 


\section{Il Macrothink}

Global Journal of Educational Studies

ISSN 2377-3936

2017, Vol. 3, No. 2

Depending on the time available, the teacher also had students work in pairs, where they helped each other with memorization but did not otherwise using the vocabulary. During this process, the students again engaged minimally with the vocabulary learning. Instead, they focused on the completion of the copying and cutting.

Typically, in the individual work, the students engaged in multimodal acts for the following functions:

1) Seeking information: Students watched what others did in order to mechanically complete the vocabulary sheet without relating vocabulary to the science content. For example,

\begin{tabular}{|l|l|l|l|}
\hline Line & Coding Categories & Speech & Nonverbal Behaviors \\
\hline 1 & $\begin{array}{l}\text { Seeking information; } \\
2\end{array}$ & $\begin{array}{l}\text { S: Dov't we need a piece of paper } \\
\text { Copying }\end{array}$ & $\begin{array}{l}\text { Y pointed to the worksheet for M as } \\
\text { if she was explaining. Then they } \\
\text { both copied. }\end{array}$ \\
\hline 3 & & E: Yeah. & \\
\hline 4 & Seeking information & S: So where are the definitions? & S leaned over to watch E's sheet. \\
\hline 5 & & E: They are right here. & \\
\hline 6 & & & \\
\hline
\end{tabular}

2) Directing: Students directed each other or themselves, both verbally and nonverbally, in how to complete the vocabulary sheet. For example,

Giving verbal direction to others:

\begin{tabular}{|l|l|l|l|}
\hline Line & Coding Categories & Speech & Nonverbal Behaviors \\
\hline 1 & Directing & S: You can write the definition. & S leaned over to watch E. \\
\hline
\end{tabular}

Giving verbal direction to self:

\begin{tabular}{|l|l|l|l|}
\hline Line & $\begin{array}{l}\text { Coding } \\
\text { Categories }\end{array}$ & Speech & Nonverbal Behaviors \\
\hline 1 & $\begin{array}{l}\text { Directing } \\
\text { (self) }\end{array}$ & E: Nucleus. & $\begin{array}{l}\text { E read the vocabulary while writing it } \\
\text { down. }\end{array}$ \\
\hline 3 & Directing & $\begin{array}{l}\text { E: There's another word here. } \\
\text { There are words over here. }\end{array}$ & $\begin{array}{l}\text { E leaned over to watch A's worksheet and } \\
\text { pointed to the words on A's textbook. }\end{array}$ \\
\hline
\end{tabular}

Giving nonverbal direction to others:

\begin{tabular}{|l|l|l|}
\hline Line & $\begin{array}{l}\text { Coding } \\
\text { Categories }\end{array}$ & Nonverbal Behaviors \\
\hline 1 & Directing & $\begin{array}{l}\text { M leaned over to watch Y's worksheet. } \\
\text { Y then took M's worksheet, looked at it, and wrote the next vocabulary word } \\
2\end{array}$ \\
3 & & on her worksheet. Y returned the worksheet to M, and M continued writing. \\
\hline
\end{tabular}


3) Checking: Students checked each other's process. For example,

\begin{tabular}{|l|l|l|l|}
\hline Line & Coding Categories & Speech & Nonverbal Behaviors \\
\hline 1 & Checking & E: Where are you now? & E looked at S. \\
\hline 2 & & S: I am numbering. & \\
\hline
\end{tabular}

4) Social chatting: Students chatted about matters irrelevant to the class topic. Social chatting happened primarily between the two male focal students in a low vocal volume. As they engaged in social chatting, they continued with their own mechanical individual work with the materials. For example,

\begin{tabular}{|c|c|c|c|}
\hline Line & $\begin{array}{l}\text { Coding } \\
\text { Categories }\end{array}$ & Speech & Nonverbal Behaviors \\
\hline 1 & \multirow{9}{*}{$\begin{array}{l}\text { Social } \\
\text { chatting }\end{array}$} & S: Is your brother working? & \multirow{9}{*}{$\begin{array}{l}\text { S began to chat with E again. } \\
\text { They both continued } \\
\text { copying the words and } \\
\text { definitions while chatting. }\end{array}$} \\
\hline 2 & & E: What? & \\
\hline 3 & & S: I said, is your brother working. & \\
\hline 4 & & E: No, he's still at school. How about yours? & \\
\hline 5 & & S: My eldest brother works. I have 3 brothers. & \\
\hline 6 & & E: What kind of work does he do? & \\
\hline 7 & & S: I don't know. He didn't tell me. & \\
\hline 8 & & E: I heard that you earn 8 dollars an hour & \\
\hline 9 & & when you work. & \\
\hline
\end{tabular}

5) Copying: Students copied the vocabulary and definitions from the textbook pages. For example,

\begin{tabular}{|l|l|l|}
\hline Line & $\begin{array}{l}\text { Coding } \\
\text { Categories }\end{array}$ & Nonverbal Behaviors \\
\hline 1 & Copying & S was the quickest to start copying the words. M watched Y and then started \\
2 & Observing & $\begin{array}{l}\text { to copy, as well. There was no talking between the students. After the } \\
\text { copying, the boys began to cut the vocabulary words off. }\end{array}$ \\
3 & &
\end{tabular}

During individual work time, the students' multimodal acts concerned where to copy the definitions, what others were doing, what procedure to follow to complete the task, telling others what to do, or they engaged in social chat irrelevant to the science learning. Students' engagement with the vocabulary focused on the procedural and social aspects of learning but not the academic aspect. They were not provided opportunities to see how the words were used in sentences and paragraphs or how to use the words to form their own sentences. As a result, any student engagement with the vocabulary, if at all, remained at the abstract level of pronouncing the words, copying the spelling, and copying the definitions.

Similarly, the teacher's multimodal acts during individual work also focused on the 
non-academic aspect of the instruction. The teacher involved the following functions:

1). Checking: The teacher checked the students' procedure. For example,

\begin{tabular}{|c|c|c|c|}
\hline Line & $\begin{array}{l}\text { Coding } \\
\text { Categories }\end{array}$ & Speech & Nonverbal Behaviors \\
\hline $\begin{array}{l}1 \\
2\end{array}$ & Checking & $\begin{array}{l}\text { T (checking E's work): This one } \\
\text { needs to be labeled. }\end{array}$ & \multirow{3}{*}{$\begin{array}{l}\mathrm{T} \text { walked to } \mathrm{E} \text { and looked at his } \\
\text { vocabulary sheet. } \\
\mathrm{E} \text { labeled the word. } \mathrm{T} \text { continued } \\
\text { looking at the sheet. }\end{array}$} \\
\hline 3 & & E: Oh, Yeah. & \\
\hline 4 & & T: Ok, you've labeled that. & \\
\hline
\end{tabular}

2). Providing help: The teacher helped the students cut their worksheets to make vocabulary cards. For example,

\begin{tabular}{|l|l|l|l|}
\hline Line & Coding Categories & Speech & Nonverbal Behaviors \\
\hline 1 & Providing help & $\begin{array}{l}\text { T: Do you need any help } \\
\text { cutting them? }\end{array}$ & T walked to a non-focal student. \\
\hline
\end{tabular}

3). Directing: the teacher directed the students to do something. For example,

\begin{tabular}{|l|l|l|l|}
\hline Line & $\begin{array}{l}\text { Coding } \\
\text { Categories }\end{array}$ & Speech & Nonverbal Behaviors \\
\hline 1 & Checking & $\begin{array}{l}\text { T: S, have you finished your } \\
\text { paper? }\end{array}$ & $\begin{array}{l}\text { T saw S standing up. T then walked to } \\
\text { him, checking his paper. }\end{array}$ \\
\hline 3 & Directing & $\begin{array}{l}\text { T: Don't turn it over. Match the } \\
\text { definitions. And when you're } \\
\text { done, I'll check it again. }\end{array}$ & $\begin{array}{l}\text { T talked to S. All other focal students } \\
\text { were still cutting their worksheets into } \\
\text { cards. }\end{array}$ \\
\hline 6 & Directing & $\begin{array}{l}\text { T (to S): OK, one of these things } \\
\text { matches with your definition. } \\
\text { You need to memorize that. }\end{array}$ & $\begin{array}{l}\text { T stood behind S and watched him. T } \\
\text { then pointed to S' vocabulary cut-out. }\end{array}$ \\
\hline 8 & & \multicolumn{2}{|l}{} \\
\hline
\end{tabular}

As these examples indicate, the teacher's multimodal acts were used exclusively for the procedural functions but not to help her students engage with the concepts undergirding the vocabulary. There was no opportunity for students to understand the words conceptually, use them, and ultimately internalize them into their own science discourse.

The teacher's rationale for this approach to individual work was,

... Let's say you write eyepiece here, you write that, and you copy this, and it takes probably less than 5 seconds to do that. Whereas I say, I want you to cut out this piece, and I want you to paste this in the correct place here. You're spending more time looking at the words. That's what I want. You learn better. Cutting makes you slow down, makes you look at the words when you are cutting, so you can get that done." 


\section{MInstitute Macrothink $_{\text {Int }}$}

The teacher ensured that the students mastered the vocabulary by quizzing them repeatedly until they had memorized at least 8 out of 10 items from the vocabulary list. Usually, since the students were not able to successfully memorize the vocabulary and their definitions without contextual, conceptual, and experiential support, they were given multiple chances to pass the quiz. On average, the teacher administered each quiz three times, and the total time used for quizzes in each unit was equal to at least half of one class period.

The typical quiz was designed as a matching game. For example, the teacher read, "One of the words has mass, and it takes up space. What is that? Write it down" The students then wrote the word. The quiz did not involve any assessment of the students' conceptual understanding of the vocabulary. For example, Figures 3, 4, and 5 show the students' quiz sheets for the "Properties of Matter" unit.

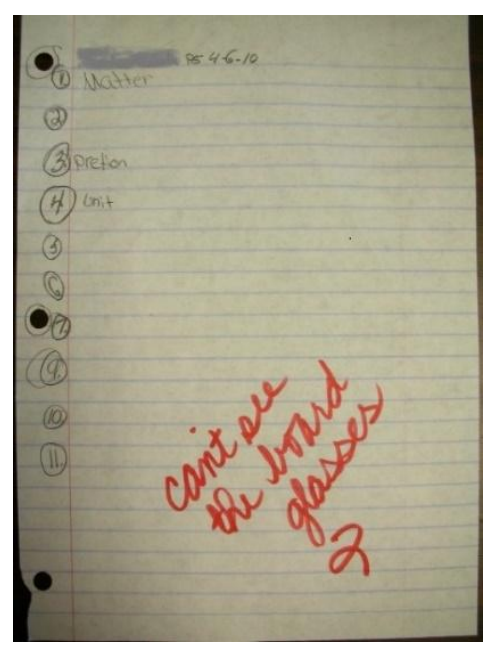

Figure 3. Santos's quiz sheet

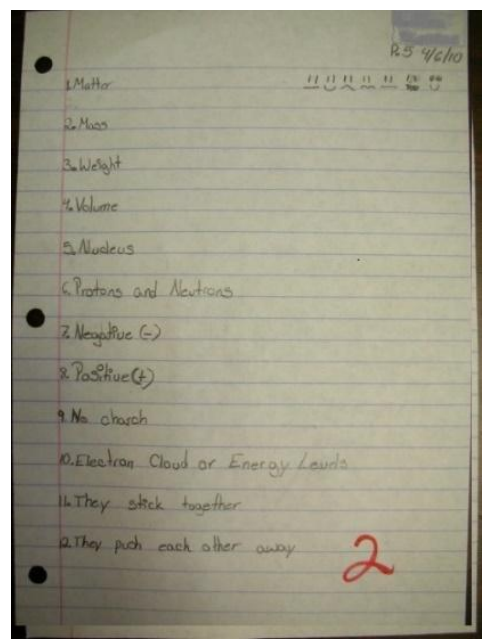

Figure 4. Ysabel's quiz sheet

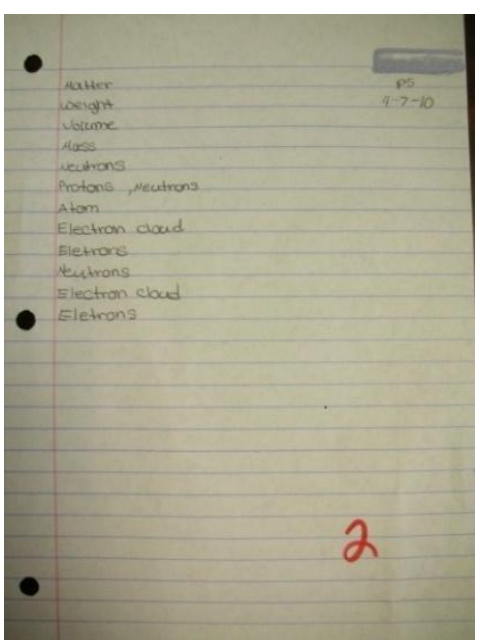

Figure 5. Marta's quiz sheet

Figure 3 shows Santos' quiz sheet as he took the quiz for the first time. He managed to write down three words: "matter," "proton," and "unit." The teacher marked Santos' paper with a red number " 2 ," indicating he had two correct answers, but in reality, the word "matter" was the only correct answer. The teacher also wrote, "Can't see the board" and "glasses" as a reminder that Santos needed a pair of glasses. Figure 4 shows Ysabel's quiz sheet. She managed to write down all 12 items, including two sentences the teacher stated. Of these 12 answers, the words "matter" and "mass" were correct. Figure 5 shows Marta's quiz sheet. Marta gave two correct answers (i.e., "matter" and "mass") out of 12 test items. Thus, the performance of the focal students on such quizzes did not show high competence in terms of matching teacher-stated definitions to new vocabulary items.

When students did not perform well on their quizzes, they were provided class time to memorize the definitions again by reviewing their vocabulary cards. Students were then asked to take the same type of quiz again. If the expectation was not met, the class repeated the cycle 
until all students passed the quiz. In the above example, all three focal students repeated the quiz three times. Regarding the students' multiple attempts, the teacher's comments to the students indicated that she attributed this to inadequate study habits. She stated, "I am very disappointed because you just did not study."

In sum, vocabulary learning sessions provided decontextualized experiences for the learning of key vocabulary through memorization and rote repetition. The vocabulary was introduced prior to the students' multimodal engagement with the science content. Thus, the key vocabulary worked as a separate entity to the overall science discourse. Student learning focused on the mechanics of task-completion instead of on the conceptual understanding of the key vocabulary as an integral aspect of the science discourse. As a result, students' language development was restricted.

\section{Discussion}

The main argument of the study regarding the language development portion is that although literacy components were embedded in science curriculum through devoted time for vocabulary learning, limited language development occurred. By examining the nature of classroom communication in vocabulary learning sessions, this study demonstrates that the class instruction did not achieve the teacher's stated instructional aims: "to learn the vocabulary" and "to recycle the language." From a social semiotics' perspective, science discourse is highly multimodal as students in science classrooms naturally engage in multiple ways of communicating, whether it is through the visual images, oral language, or written language (Kress et al., 2001; Lemke, 1998; Márquez, Izquierdo, \& Espinet, 2006). In the studied classroom, the teacher constantly used visual images for vocabulary and literacy instruction; for example, in the vocabulary learning session shown in Table 1, she incorporated a visual image of a microscope to help students visualize the key science words. The inclusion of multimodal teaching, however, did not seem to mediate students' language development, nor their science learning. As the data on vocabulary learning sessions show, students and teacher actively engaged with the procedural and social aspects of the classroom discourse, such as seeking information, checking each other's process, and social chatting, but not with the academic aspect of the content learning. Students' interaction with the science vocabulary was limited as there were no opportunities provided for students to interact with the science words in constructing their science knowledge. All interactions remained at the receptive level; that is, students were hearing, looking, and, at most, pronouncing the science language, but at no point, did they engage in active use of the language for the purpose of learning the content. The lack of linguistic "output" (Swain, 1985, 1993) situated in the classroom discourse hindered students' language development, which may be shown through students' vocabulary quizzes. As a result, the classroom instruction achieved neither instructional nor language objectives.

These findings suggest that the science discourse in this classroom featured a disconnection between science learning and language development. Although the teacher realized the importance of incorporating language studies into the science curriculum, language teaching was conceptualized and operated as a separate entity from the science discourse. It was viewed as a "prerequisite" and taught in a decontextualized manner apart from content learning. This 
reflects a simplistic view of academic language only as vocabulary separated from the discourse, which seems not uncommon among content teachers (Richardson Bruna, Vann, \& Perales Escudero, 2007; Van Lier \& Walqui, 2012). What is missing is a more comprehensive understanding of science language, including the science vocabulary, academic language functions, and the discourse features. Quinn, Lee, and Valdés (2012) mentioned:

Science discourse at any level requires students to attend to and argue about precise meanings. This demand for attention to precision and attention to detail goes beyond the meaning of technical vocabulary, to the evidence and logic of connecting cause and effect, and the validity of claims or warrants. (p. 6)

Research reveals that science language carries specific linguistic features (Fang, 2006; Halliday, 1993; Martin \& Veel, 1998) and fulfill unique academic functions (Carr, Sexton, \& Lagunoff, 2007). Without a comprehensive understanding of how language functions to deliver the science content, the teacher provided instruction targeting at the word level, assuming students could produce sophisticated science discourse by simply learning the vocabulary in isolated contexts.

This simplistic view of science language along with the particular classroom practice which "frontloads" the science vocabulary ahead of the content learning seem have been problematized in research (Brown \& Ryoo, 2008; Settlage, J., Madsen, A., \& Rustad, 2005) and recent professional development studies seek a more integrated approach to merge science literacy into the instructional activities (Gibbons, 2009; Shaw, Lyon, Stoddart, Mosqueda, \& Menon, 2014; Weinburgh et al., 2014; Zwiep et al., 2011). For example, in Shaw and colleagues' study (Shaw et al., 2014), science literacy was addressed through active use of the content terms by the teacher and sufficient opportunities for students to use these words as well. In Weinburgh and colleagues' study (Weinburgh et al., 2014), they described a 5R instructional model in which the vocabulary instruction was woven into the inquiry science. The interview data and statistics showed that students had significant gains in academic language and conceptual understanding. Nonetheless, the actual teaching world continues to separate the language from content learning, and the study described above echoes what the research has been arguing about the distorted image of language in content areas. It raises the alarm to the educational field about how to successfully incorporate language teaching into the content area curriculum. In the standard era, this issue becomes even more urgent for teachers, administrators, and teacher educators.

\section{Limitations and Suggestions for Future Research}

By portraying what happens in a six-grade sheltered science classroom, this study shows that although literacy components were deliberately embedded in the science teaching, language development suffered due to the conceptual and practical disconnections between the language and content. I acknowledge the limitation of the study. As a qualitative study with four participants from one classroom, the research cannot be used to generalize a more overall conclusion; however, the study provides vivid classroom scenes in which the language instruction, although intended, fails to help students gain linguistic and conceptual knowledge of the science content. 


\section{Al Macrothink}

Global Journal of Educational Studies

ISSN 2377-3936

2017, Vol. 3, No. 2

Current literature about science education for ELs generally focuses on students' science achievement by relying on the quantitative data, such as test scores (Amaral et al., 2002; Buxton et al., 2008; Lara-Alecio et al., 2012; Santau et al., 2011; Santau et al., 2010; Shanahan \& Shea, 2012). In order to understand how science language develops in classroom settings, future research that specifically looks at actual classroom practices may be desired. Questions such as how are the languages as well as other semiotic resources used to mediate students' science learning are worthy answering through careful research design.

The study also provides a valuable lesson for future work in teacher education and teacher training. Some studies have already focused on the integration of language and content in science teacher education courses (Stoddart et al., 2011; Weinburgh et al., 2014). Such research should be used as references for future teacher education.

\section{Acknowledgement}

I thank Dr. Susan Britsch and Dr. Daniel Shepardson, Department of Curriculum and Instruction at Purdue University, for their guidance on this study.

\section{References}

Amaral, O. M., Garrison, L., \& Klentschy, M. (2002). Helping English Learners increase achievement through inquiry-based science instruction. Bilingual Research Journal, 26(2), 213-239. https://doi.org/10.1080/15235882.2002.10668709

Bogdan, R., \& Biklen, S. K. (2006). Qualitative research for education: An introduction to theories and methods (5th ed.). Boston, Mass: Pearson.

Britsch, S. (2005). The multimodal mediation of power in the discourses of preschool story designers. Text: An Interdisciplinary Journal for the Study of Discourse, 25(3), 305-340. https://doi.org/10.1515/text.2005.25.3.305

Britsch, S. (2009). Differential discourses: the contribution of visual analysis to defining scientific literacy in the early years classroom. Visual Communication, 8(2), 207-228. https://doi.org/10.1177/1470357209102114

Brown, B. A., Ryoo, K., \& Rodriguez, J. (2010). Pathway towards fluency: Using "disaggregate instruction"to promote science literacy. International Journal of Science Education, 32(11), 1465-1493. Retrieved from http://www.tandfonline.com/doi/abs/10.1080/09500690903117921

Buxton, C., Lee, O., \& Santau, A. (2008). Promoting science among English Language Learners: Professional development for today's culturally and linguistically diverse classrooms. Journal of Science Teacher Education, 19(5), 495-511. https://doi.org/10.1007/s10972-008-9103-X

Carr, J., Sexton, U., \& Lagunoff, R. (2007). Making science accessible to English learners: a guidebook for teachers. WestEd.

Echevarria, J. J., Vogt, M., \& Short, D. J. (2012). Making Content Comprehensible for English 
Learners: The SIOP Model (4th ed.). Boston: Pearson.

Fang, Z. (2006). The Language Demands of Science Reading in Middle School. International Journal of Science Education, 28(5), 491-520. https://doi.org/10.1080/09500690500339092

Flewitt, R., Hampel, R., Hauck, M., \& Lancaster, L. (2009). What are multimodal data and transcription? In C. Jewitt (Ed.), The Routledge handbook of multimodal analysis (pp. 40-53). London, New York: Routledge.

Garvey, C. (1984). Children's talk: The developing child. Cambridge, MA: Harvard University Press.

Gee, J. P. (1999). An introduction to discourse analysis: Theory and method. NewYork: Routledge.

Gibbons, P. (2009). English learners, academic literacy, and thinking: Learning in the challenge zone. Portsmouth, NH: Heinemann.

Halliday, M. A. K. (1978). Language as social semiotic. London: Edward Arnold.

Halliday, M. A. K. (1993). On the language of physical science. In M. A. K. Halliday \& J. R. Martin (Eds.), Writing science: Literacy and discursive power (pp. 54-68). London: The Falmer Press.

Hodge, B., \& Kress, G. (1988). Social semiotics. Ithaca, N.Y.: CornEL University Press.

Jewitt, C. (2006). Technology, literacy and learning: a multimodal approach. London; New York: Routledge.

Knapp, M., \& Hall. J. (1997). Nonverbal communication in human interaction. Fort Worth, TX: Fort Worth Harcourt Brace College Publishers.

Kress, G. R. (1997). Before writing: rethinking the paths to literacy. London; New York: Routledge.

Kress, G., Jewitt, C., Ogborn, J., \& Tsatsarelis, C. (2001). Multimodal Teaching and Learning: The Rhetorics of the Science Classroom. New York: Continuum.

Lara-Alecio, R., Tong, F. H., Irby, B., Guerrero, C., Huerta, M., \& Fan, Y. N. (2012). The effect of an instructional intervention on Middle School English Learners' science and English reading achievement. Journal of Research in Science Teaching, 49(8), 987-1011. https://doi.org/10.1002/tea.21031

Lee, O., Penfield, R., \& Buxton, C. (2011). Relationship between "form" and "content" in science writing among English Learners. Teachers College Record, 113(7), 1401-1434.

Lemke, J. L. (1990). Talking science: Language, learning, and values. New York: Ablex Pub. Lemke, J. L. (1998). Teaching all the languages of science: words, symbols, images, and actions. Retrieved from http://academic.brooklyn.cuny.edu/education/jlemke/papers/barcelon.htm 
Márquez, C., Izquierdo, M., \& Espinet, M. (2006). Multimodal science teachers' discourse in modeling the water cycle. Science Education, 90(2), 202-226. https://doi.org/10.1002/sce.20100

Martin, J. R., \& Veel, R. (Eds.). (1998). Reading science: Critical and functional perspectives on discourses of science. London: Routledge.

Palmer, G. B. (1996) Toward a Theory of Cultural Linguistics. Austin: University of Texas Press.

Quinn, H., Lee, O., \& Valdés, G. (2012). Language demands and opportunities in relation to Next Generation Science Standards for English Language Learners: What teachers need to know. Paper Presented at the Understand Language Conference, Stanford, CA. Retrieved from http://EL.stanford.edu/sites/default/files/pdf/academic-papers/03-Quinn\%20Lee\%20Valdes\% 20Language $\% 20$ and $\% 20$ Opportunities\%20in\%20Science\%20FINAL.pdf

Richardson Bruna, K., Vann, R., \& Perales Escudero, M. (2007). What's language got to do with it?: A case study of academic language instruction in a high school "English Learner Science" class. Journal of English for Academic Purposes, 6(1), 36-54. https://doi.org/10.1016/j.jeap.2006.11.006

Rosebery, A. S., \& Warren, B. (2008). Teaching Science to English Language Learners: Building on Students'Strengths. NSTA Press.

Santau, A. O., Maerten-Rivera, J. L., \& Huggins, A. C. (2011). Science Achievement of English Language Learners in Urban Elementary Schools: Fourth-Grade Student Achievement Results from a Professional Development Intervention. Science Education, 95(5), 771-793. https://doi.org/10.1002/sce.20443

Santau, A., Secada, W., Maerten - Rivera, J., Cone, N., \& Lee, O. (2010). US urban elementary teachers' knowledge and practices in teaching science to English Learners: Results from the first year of a professional development intervention. International Journal of Science Education, 32(15), 2007-2032. https://doi.org/10.1080/09500690903280588

Settlage, J., Madsen, A., \& Rustad, K. (2005). Inquiry science, sheltered instruction, and English language learners: Conflicting pedagogies in highly diverse classrooms. Issues in Teacher Education, 14(1), 39-57.

Shanahan, T., \& Shea, L. M. (2012). Incorporating English language teaching through science for K-2 teachers. Journal of Science Teacher Education, 23(4), 407-428. https://doi.org/10.1007/s10972-012-9276-1

Shaw, J., Lyon, E., Stoddart, T., Mosqueda, E., \& Menon, P. (2014). Improving Science and Literacy Learning for English Language Learners: Evidence from a Pre-service Teacher Preparation Intervention. Journal of Science Teacher Education, 25(5), 621-643. https://doi.org/10.1007/s10972-013-9376-6

Stoddart, T., Bravo, M., Solis, J., Mosqueda, E., \& Rodriguez, E. (2011). Effective science teaching for English language learners (ESTEL): Measuring pre-service teacher practices. 
Paper Presented at the Annual Meeting of the American Educational Research Association, New Orleans, LA. Retrieved from http://education.ucsc.edu/estEL/Stoddart_et_al_2011_AERA.pdf

Swain, M. (1985). Communicative competence: Some roles of comprehensible input and comprehensible output in its development. In S. Gass \& C. Madden, Input in Second Language Acquisition (pp. 235-256). New York: Newbury House.

Swain, M. (1993). The output hypothesis: Just speaking and writing aren't enough. Canadian Modern Language Review, 50(1), 158-164.

Valdés, G., Kibler, A., \& Walqui, A. (2014). Changes in the expertise of ESL professionals: Knowledge and action in an era of new standards. Alexandria, VA: TESOL International Association.

Van Leeuwen, T. (2004). Ten reasons why linguists should pay attention to visual communication. In P. LeVine \& R. Scollon (Eds.), Discourse and technology: Multimodal discourse analysis (pp. 7-19). Washington, DC: Georgetown University Press.

Van Leeuwen, T. (2005). Introducing Social Semiotics: An Introductory Textbook (1st ed.). London; New York: Routledge.

Van Lier, L., \& Walqui, A. (2012). Language and the Common Core State Standards. Paper Presented at the Understand Language Conference, Stanford, CA. Retrieved from http://EL.stanford.edu/sites/default/files/pdf/academic-papers/04-Van\%20Lier\%20Walqui\%2 OLanguage $\% 20$ and $\% 20$ CCSS\%20FINAL.pdf

Walqui, A. (2011). The growth of teacher expertise for teaching English Language Learners: A socio-culturally based professional development model. In T. Lucas, Teacher preparation for linguistically diverse classrooms: A resource for teacher educators (pp. 160-177). New York, NY: Routledge.

Weinburgh, M., Silva, C., Smith, K. H., Groulx, J., \& Nettles, J. (2014). The Intersection of Inquiry-Based Science and Language: Preparing Teachers for ELL Classrooms. Journal of Science Teacher Education, 25(5), 519-541. https://doi.org/10.1007/s10972-014-9389-9

Zhang, (2016). Multimodal teacher input and science learning in a middle school sheltered classroom. Journal of Research in Science Teaching, 53(1), 7-30. https://doi.org/10.1002/tea.21295

Zwiep, S., Straits, W., Stone, K., Beltran, D., \& Furtado, L. (2011). The Integration of English Language Development and Science Instruction in Elementary Classrooms. Journal of Science Teacher Education, 22(8), 769-785. https://doi.org/10.1007/s10972-011-9254-z 


\section{Appendix}

\section{Appendix 1. Levels of English language proficiency}

\begin{tabular}{|l|l|}
\hline Levels & Description \\
\hline Level 1 & $\begin{array}{l}\text { At Level1, students have limited or no understanding of English. They generally } \\
\text { use nonverbal communication to respond to simple questions and commands. At } \\
\text { most, they may produce single words or simple phrases. }\end{array}$ \\
\hline Level 2 & $\begin{array}{l}\text { At Level 2, students can understand phrases and short sentences. They can } \\
\text { produce rudimentary sentences about everyday experiences but cannot } \\
\text { comprehend academic language. Errors in writing often hinder communication. }\end{array}$ \\
\hline Level 3 & $\begin{array}{l}\text { At L3, students can understand more complex speech used within and outside the } \\
\text { school. Students may comprehend academic language through instructional and } \\
\text { linguistic accommodations. They can produce simple sentences with grammatical } \\
\text { errors. }\end{array}$ \\
\hline Level 4 & $\begin{array}{l}\text { At L4, students are capable of having everyday communication. They are able to } \\
\text { read independently and comprehend most academic text. However, they may have } \\
\text { difficulties understanding concepts presented in a decontextualized manner. They } \\
\text { may also have difficulties understanding sentences with complex structure and/or } \\
\text { technical vocabulary. }\end{array}$ \\
\hline Level 5 & $\begin{array}{l}\text { At L5, students can understand language as it is used for instructional purposes. } \\
\text { They can produce language appropriate for general, social, and/or academic } \\
\text { purposes in a variety of contexts. Language generally contains minimal errors. }\end{array}$ \\
\hline
\end{tabular}

Adapted from TESOL International Association. (2006). PreK-12 English Language Proficiency Standards. TESOL Publications.

\section{Appendix 2. Protocols of formal interviews}

Part A: Students' backgrounds

1. May I know your age?

2. Were you born in the United States or did you move to the United States later?

3. When did you begin your school in the United States? And when did you start learning English?

4. How do you use Spanish and English in your life?

5. Among all your school subjects, including English language arts, social studies, science, and math, which one do you like best? And why?

6. Tell me something about learning science with Mrs. Harry.

Part B. Classroom activities and lab experiences

1. Tell me about what you did in this class/lab. Here is a new piece of paper, if you want, you can write or draw while you talk. 
2. What did you think you learned in the class/lab?

3. Could you tell me something about your product/journal writing/data sheet?

4. If you would do this activity/lab again, would you change anything? Why?

Part C. Teacher's thoughts about science teaching and ELs

1. How long have you been teaching? Which subject(s) and which grade level(s) have you been teaching? How long have you been teaching English Language Learners? Tell me something about your experience working with ELs.

2. What curriculum did you use? Who made the decision about the curriculum? When the curriculum was decided, was there any support or training provided to you or to other teachers?

3. What does teaching science mean to you? Why?

4. How do you see the relationship between language skills and science learning? Did you use any particular method or strategy to help ELs to learn?

5. For the four focal students, what have you noticed about their science learning?

\section{Appendix 3. Coding categories}

Semiotic functions:

- Academic function: Multimodal acts (verbal and nonverbal) used as classroom functions that center in curriculum content.

- Procedural function: Multimodal acts (verbal and nonverbal) used as classroom functions that aim to establish and maintain orders of actions.

- Social function: Multimodal acts (verbal and nonverbal) used as classroom functions with interpersonal and social purposes.

Pragmatic functions:

- Checking: Multimodal acts used to examine student work.

- Commenting: Multimodal acts used to add new pieces of information.

- Copying: Actions used to copy.

- Describing: Multimodal acts used to describe visual products or science phenomenon.

- Directing: Multimodal acts used to give instructions and directions to the students.

- Introducing: Multimodal acts used to bring science content to the students for the first time.

- Observing: Multimodal acts used to attend to something to obtain information. 
- Providing help: Multimodal acts used to offer help to someone.

- Reading aloud: Multimodal acts used to read written words, sentences or paragraphs from the textbook, journal entries, worksheets, and visual products.

- Seeking information: Multimodal acts used to ask for more information.

- Social Chatting: Multimodal acts used to engage in social topics.

\section{Copyright Disclaimer}

Copyright for this article is retained by the author(s), with first publication rights granted to the journal.

This is an open-access article distributed under the terms and conditions of the Creative Commons Attribution license (http://creativecommons.org/licenses/by/3.0/). 